\title{
The Handling Of Hoax/False Information In The Legal Jurisdiction Area
}

\section{Nur Cahyo Ari Prasetyo*) and Sri Endah Wahyuningsih ${ }^{* *}$}

*)National Police of Central Java Police's Human Resources Bureau, E-mail: ncahyoap@gmail.com

${ }^{* *}$ ) Faculty of Law Universitas Islam Sultan Agung

\begin{abstract}
This study aims to identify and analyze the handling of hoaxes in the jurisdiction of the Central Java Regional Police and the obstacles faced in handling hoaxes in the jurisdiction of the Central Java Regional Police. The approach method used is sociological juridical, descriptive analytical research specifications, types and sources of data using primary and secondary data, data collection methods are field studies and literature studies, while the data analysis method uses qualitative analysis. The results showed that phandling hoaxes in the jurisdiction of the Central Java Regional Police through preemptive, preventive and repressive efforts which are the last resort. The handling of hoaxes at the Central Java Regional Police is in line with progressive legal theory which is based on the principle that the law is for humans. In handling hoaxes, there are several obstacles faced, namely the difficulty of finding perpetrators, difficulties in uncovering evidence, the lack of facilities and infrastructure, the budget required for handling hoaxes is very large, differences in legal perspectives from the founding countries of social media. These obstacles are an inhibiting factor in law enforcement.

Keywords: Handling; Hoax; Social Media.
\end{abstract}

\section{Introduction}

The current era of globalization is marked by advances in science and technology that make there are no boundaries of distance and time. In addition, current technological developments have also created a condition characterized by volatility, uncertainty, complexity, and ambiguity, also known as the VUCA acronym. This condition occurs due to very rapid dynamic changes in various aspects such as social, economic and political. ${ }^{1}$

Advances in technology basically bring both positive and negative sides to mankind. One of the most obvious negative impacts of technological advances is the spread of hoax information in cyberspace. ${ }^{2}$ Freedom of expression is not accompanied by public understanding of the essence of freedom of opinion and a sense of responsibility in its implementation. As a result, many hoax cases are carried out through social media. ${ }^{3}$

\footnotetext{
1 Komjen Listyo Sigit Prabowo, Transformasi Menujuu Polri Yang Presisi, disampaikan pada Uji Kelayakan dan Kepatuhan Calaon Kapolri di Hadapan Komisi III DPR RI in 2021.

2 Subkhan, Hoak Dalam Perspektif Islam, Makalah, disampaikan dalam Kajian Islam Bersama MUI Kudus, July 5, 2019.

3 Zaldy Kurniawan, "Police Role In The Handing of Hate Speech", Jurnal Daulat Hukum, Volume 1 Issue 2, June 2018, url : http://jurnal.unissula.ac.id/index.php/RH/article/view/3260/2396
} 
Hoax has become a national problem including division, political instability and security disturbances that have the potential to hinder national development. ${ }^{4}$ According to Gumilar, hoax is information that is engineered in such a way as to cover the actual information. In other words, hoax can also be interpreted as an attempt to distort facts using information that seems convincing but cannot be verified. ${ }^{5}$

The development of internet penetration in Indonesia has made social media platforms such as Facebook, Twitter, WhatsApp, Instagram, and others an effective means for distributing hoaxes. ${ }^{6}$ According to Antaranews.com news on January 30, 2021, the Ministry of Communication and Information (Kominfo) noted that in the last one to two years there have been more than 2,000 hoax content in cyberspace, of which 30 percent are hate speech based on ethnicity, religion, race and intergroup (SARA). ). ${ }^{7}$

Hoaxon social media is regulated in Article 28 paragraph (1) of Act No. 11 of 2008 concerning Information and Electronic Transactions as amended to Act No. 19 of 2016 (UU ITE) which states that everyone intentionally and without rights spreads false and misleading news which results in consumer losses in Electronic Transactions. The criminal provisions are regulated in Article 45A paragraph (1) of the ITE Law which states that anyone who intentionally and without rights spreads false and misleading news that results in consumer losses in Electronic Transactions as referred to in Article 28 paragraph (1) shall be punished with imprisonment of at most 6 (six) years and/or a maximum fine of IDR $1,000,000,000.00$ (one billion rupiah).

Normative legal regulations to prevent hoaxes include the Criminal Code and Act No. 11 of 2008 concerning Information and Electronic Transactions as amended into Act No. 19 of 2016 (UU ITE). However, these regulations have not been able to maximally stem the hoax information that is currently developing, especially against hoaxes that use and or are wrapped in religious nuances.

Police is one of the functions of state government in the field of maintaining security and public order, law enforcement, protection, protection, and service to the community as mandated in Article 5 of Act No. 2 of 2002 concerning the Indonesian National Police. In handling hoaxes, the National Police not only implement law enforcement but are required to make breakthroughs by

\footnotetext{
4Yanto Irianto, "Enforcement Of Criminal Law In False News (Hoax) Management According To Law No. 11 In 2008 That Has Been Amended To Be Law No.19 Of 2016 Concerning Electronic Information And Transactions In Islamic Law And Positive Laws", The 5th International Conference and Call for Paper Faculty of Law 2019 Sultan Agung Islamic University, url : http://jurnal.unissula.ac.id/index.php/apic/article/view/7854

${ }^{5}$ Humaizi, Siti Hazzah Nur Ritongga, "Upaya menanggulangi hoax melalui literasi media pada anggota Karang Taruna Desa Tandem Hilir I Kecamatan Hamparan Perak", Indonesian Journal of Community Services, Volume 1, No. 2, November 2019, url : http://jurnal.unissula.ac.id/index.php/ijocs/article/view/5004/3454

${ }^{6}$ Subhan HI. Ali Dodego, Pandangan Islam Tentang Hoaks Dan Ujaran Kebencian Dalam Konteks Kekinian (Telaah Tafsir Al-Qur'an Surah Al-Hujurat Ayat:6), url : https://pionir.uinmalang.ac.id/assets/uploads/berkas/artikel\%2018.pdf

7 Kementrian Kominfo Catat 2000 Lebih Hoaks, 30 Persen Ujaran Kebencian, https://www.antaranews.com, accessed 20 April 2021.
} 
prioritizing preemptive and preventive efforts to maintain public security and order.

In the jurisdiction of the Central Java Regional Police, an average of 30 to 40 hoax news are found on social media, which are related to false news or hate speech. ${ }^{8}$ Although cyber patrols have been carried out to monitor and search for hoax news spread on social media, hoaxes are still difficult to contain. This study aims to determine and analyze the handling of hoaxes in the jurisdiction of the Central Java Regional Police and the obstacles faced in handling hoaxes in the jurisdiction of the Central Java Regional Police.

\section{Research Methods}

The approach method used in this research is sociological juridical, research based on normative legal science (laws and regulations), but not studying the norm system but observing how the reactions and interactions occur when the norm system works in society. ${ }^{9}$ The research specification is descriptive analytical, which describes in detail and systematically the handling of hoaxes, the sources and types of data used are primary data and secondary data. The data collection method is carried out through field studies and literature studies while the data analysis method uses qualitative analysis.

\section{Results and Discussion}

\subsection{Handling Hoaxes in the Legal Territory of the Central Java Police}

The police is a subsystem in the criminal justice system which is sufficient to determine the success of the entire system in providing services to the community. This is because the police is a subsystem that is directly related to the community, so that the duties and responsibilities of the police can be said to be greater than other subsystems. ${ }^{10}$

Based on the results of research at the Central Java Police, it is known that the handling of hoaxes in the jurisdiction of the Central Java Police is carried out in a preemptive, preventive and repressive manner. The preemptive effort made by the Central Java Police is to form a virtual police or cyber police as a follow-up to the Circular Letter of the Chief of Police Number SE/2/II/2021on Ethical Cultural Awareness to Create a Clean, Healthy, and Productive Indonesian Digital Space. ${ }^{11}$

Virtual police consisting of the Public Relations and Criminal Investigation Police who are tasked with conducting cyber patrols looking for negative content

8 Tiap Hari Temukan Puluhan Informasi Hoax Polda Jateng Tingkatkan Patroli Cyber, https://halosemarang.id, accessed 20 June 2021.

${ }_{9}$ Mukti Fajar ND and Yulianto Achmad, 2013, Dualisme Penelitian Hukum Normatif dan Empiris, Yogyakarta: Pustaka Pelajar p.47.

${ }^{10}$ Eddy Santoso, Sri Endah Wahyuningsih, and Umar Ma'ruf, "Peran Kepolisian Dalam Sistem Peradilan Pidana Terpadu Terhadap Penanggulangan Tindak Pidana Perjudian", Jurnal Daulat Hukum Vol. 1. No. 1 March 2018, url :http://jurnal.unissula.ac.id/index.php/RH/article/view/2632 ${ }^{11}$ Results of an interview with Police Commissioner Victor Ziliwu, as staff of the Ditreskrimsus Polda Central Java, Semarang, on June 20, 2021. 
in cyberspace. If negative content is found, including hoaxes, it will be investigated who the owner of the account / actor who uploaded the content is, then education will be given by giving understanding to the owner of the account that uploaded the cash. If the uploader admits, then an apology letter and video testimonial will be made. The video is then uploaded to the uploader's account and the case is declared closed. Thus the case will not be escalated to an investigation. ${ }^{12}$

The activities carried out by the Central Java Police in dealing with hoaxes preemptively are as follows: ${ }^{13}$

- Conducting outreach activities to the public about the importance of being wise in using social media both directly and through advertisements on print media, television media and social media.

- Conducting Cyber Patrols to minimize the occurrence of online crime.

- Take down content that is suspected to contain elements of a violation of fake news

- Provide clear and correct comparative information to explain that the fake news is not true.

Preventive handling of hoaxes is carried out through restorative justice by referring to Article 12 of Perkap 16 of 2019. Preventive handling of hoax news that has often been carried out by investigators of Sub-Directorate V/Cyber Ditreskrimsus Polda Central Java are as follows: ${ }^{14}$

- Make a statement letter containing an acknowledgment of guilt and will not repeat the act;

- Doing clarification and apologies in written and verbal forms that are documented;

- In making points $\mathrm{a}$ and $\mathrm{b}$ witnessed by the police and local government officials and the family.

Repressive handling of hoax news can be done like handling cases in general as stated in the Criminal Procedure Code. Starting from receiving reports to coercive measures in the form of searches, seizures, arrests, detentions, to sending suspects and evidence (Phase II) to the Public Prosecutor. ${ }^{15}$

In terms of repressive handling (investigations), the Police prioritize mediation or restorative justice efforts. The stages for conducting mediation are as follows: 16

- Presenting both parties between the reported and the complainant (victims of the false news) through invitations/calls regarding mediation.

- Prepare a comfortable place and room for mediation.

- The position of the reported and the reported face to face.

- If necessary, investigators are allowed to witness the mediation but are passive and may not pressure or interfere with any party.

\footnotetext{
12 Ibid.

13 Ibid

14 Ibid.

15 Ibid.

16 Ibid.
} 
- The results of the mediation and documentation are poured into the Mediation BA and the results are conveyed to the Management in the form of a Mediation Result Report.

The data obtained from the Central Java Police regarding the handling of hoaxes are as follows:

\section{Table of Settlement of Hoax Cases at the Central Java Regional Police from 2018 to 2021}

\begin{tabular}{lccl}
\hline No & Year & Amount & Case settlement \\
\hline 1 & 2018 & 1 & P21 \\
\hline 2 & 2019 & 3 & $\begin{array}{l}1 \text { case was transferred to the West Java } \\
\text { Police, } \\
1 \text { case SP2, 1 case P21 }\end{array}$ \\
\hline 3 & 2020 & 3 & 2 cases of SP2, 1 case of P21 \\
\hline 4 & $\begin{array}{c}\text { until June } \\
2021\end{array}$ & 1 & P21 \\
\hline
\end{tabular}

Source: Central Java Police Sub-Directorate V/Cyber, 2021

Based on the table above, it is known that not all incoming reports proceed to the prosecution stage. There are several cases that have been stopped because they are at the investigation or investigation stage. The handling of hoaxes that have gone up to the investigation stage is a hoax case that creates a sense of hatred, hostility, of certain individuals and or groups of people based on race, ethnicity, and inter-group (SARA) as regulated in Article 45A paragraph (2) in conjunction with Article 28 paragraph 2 of the ITE Law. In addition, there are also hoax cases that cause consumer losses as regulated in Article 45A paragraph (1) of Act No. 19 of 2016.

The handling of hoaxes at the Central Java Regional Police prioritizes preemptive and preventive efforts rather than repressive efforts. This is in line with the Circular Letter of the Chief of Police Number SE/2/II/2021, which states that: In the context of fair law enforcement, the National Police always prioritizes education and persuasive steps so as to avoid any suspected criminalization of reported persons and can ensure that Indonesia's digital space remains clean, healthy, ethical and productive. In this case, the National Police must prioritize pre-emptive and preventive efforts through:virtual police and virtual alerts aimed at monitoring, educating, warning, and preventing the public from potential cybercrimes. Through these efforts, it is hoped that it can suppress hoaxes and repressive efforts are the last resort taken.

Handling hoaxes through virtual police is a breakthrough from the National Police in line with progressive legal theory. Progressive is changing rapidly, making fundamental reversals in legal theory and practice, and making various breakthroughs. Progressive legal theory is based on the principle that the law is for humans and not vice versa and the law does not exist for itself, but for something wider, namely for human dignity, happiness, welfare, and human glory. Progressive law is a series of radical actions, by changing the legal system 
(including changing legal regulations if necessary) so that the law is more useful, especially in raising self-esteem and ensuring human happiness and welfare. ${ }^{17}$

\subsection{Obstacles Faced in Handling Hoaxes in the Legal Territory of the Central Java Police}

The handling of hoaxes by the Central Java Police experienced several obstacles, namely as follows: ${ }^{18}$

- Difficulty finding the culprit

In handling hoaxes, it must be explored who the perpetrators of the content spreaders are. This is a separate obstacle, where many hoax crimes are carried out through social media such as Twitter, Instagram, Facebook and others as well as using fake accounts. So that investigators need to know who the social media users are in order to fulfill the elements of whom.

- Difficulty in uncovering evidence

Police officers cannot simply arrest a person suspected of having committed a hoax violation because they must have sufficient evidence to arrest him. In this case, the police must be careful in taking samples of evidence in the case of hoaxes. Given that hoaxes through social media rely heavily on evidence in the form of electronic devices that are used as a means to commit fraudulent news violations such as cellphones and laptops. In addition to electronic tools, hoaxes also use social media accounts such as Instagram and Facebook accounts, which often often use fake accounts that make it difficult to find the account owner or the perpetrator of the fake news violation.

- Lack of facilities and infrastructure

The factor of facilities and infrastructure is an obstacle faced by the police. Considering the search for the perpetrators requires some special tools that only a few police stations have.

- The budget needed in handling hoaxes is very large

In proving a false news violation case through social media, investigators need to use the services of an expert as part of the evidence in the investigation process. Where there are 3 (three) experts used, namely linguists, criminal experts, digital forensic experts and ITE experts. Which of these expert statements requires significant operational costs and expert fees. And the budget from the government for investigations and investigations given to investigators is limited and minimal.

- Differences in legal perspective from the country where social media is founded

As it is known that the founder of social media Facebook Mark Elliot Zuckerberg was born in an area called Dobbs Ferry, Westchester County, New York City, America. Where Facebook's headquarters stands in Menlo Park, Silicon Valley, the center of the creative industry in the United States. So that social media Facebook follows the rules of law in America. Not only Facebook, other social media accounts such as Instagram, Whatsapp, Twitter, most of

${ }^{17}$ Satjipto Rahardjo, 2007, Membedah Hukum Progresif , Jakarta: Kompas, p. 154.
${ }^{18}$ Interview, Loc.Cit. 
which are owned by Facebook owners and have their head office in America, also follow the rules of law in America. Due to the different legal perspectives, investigators have difficulty in finding information on a social media account. Which of the laws in America will provide information about a social media account that only contains cases of child pornography, terrorism and drug abuse. Apart from these three cases, Facebook and several social media accounts will not provide any information.

The obstacles in handling hoaxes above are obstacles encountered in the criminal law enforcement process (investigation stage). According to Soerjono Soekanto, several factors that influence law enforcement are the legal factor itself, law enforcement factors, facilities and infrastructure factors and community factors. 19

Judging from the legal factor, there are differences in legal perspectives from the country where social media is established so that the Central Java Police have difficulty in uncovering hoax cases because they must comply with the regulations of the founding country of social media. Judging from the factors of facilities and infrastructure, to uncover cases of hoaxes at the Central Java Regional Police, there are still minimal facilities and infrastructure including the budget. Judging from law enforcement factors, it is still difficult to find evidence and perpetrators of hoax spreaders. These factors are inhibiting factors in handling hoaxes at the Central Java Police.

\section{Closing}

Handling hoaxes in the jurisdiction of the Central Java Regional Police through preemptive, preventive and repressive efforts which are the last resort. The handling of hoaxes at the Central Java Regional Police is in line with progressive legal theory which is based on the principle that the law is for humans. In handling hoaxes, there are several obstacles faced, namely the difficulty of finding perpetrators, difficulties in uncovering evidence, the lack of facilities and infrastructure, the budget required for handling hoaxes is very large, differences in legal perspectives from the founding countries of social media. These obstacles are an inhibiting factor in law enforcement. So that hoaxes can be handled optimally, it is necessary to cooperate with countries where social media is established to synchronize legal regulations that regulate hoaxes on social media. In addition, there is also a need for continuous education for the community to use social media wisely and not be influenced by hoaxes spread by irresponsible actors.

\section{References}

\section{Books}

[1] Komjen Listyo Sigit Prabowo, Transformasi Menujuu Polri Yang Presisi, disampaikan pada Uji Kelayakan dan Kepatuhan Calaon Kapolri di Hadapan Komisi III DPR RI Tahun 2021.

\footnotetext{
${ }^{19}$ Soerjono Soekanto, 2004, Faktor-Faktor Yang Mempengaruhi Penegakan Hukum, Jakarta : PT. Raja Grafindo Persada, p. 6-7
} 
[2] Mafindo, 2018, Tool Kit Penanganan Hoaks dan Disinformasi, Jakarta 2018.

[3] Mukti Fajar ND dan Yulianto Achmad, 2013, Dualisme Penelitian Hukum Normatif dan Empiris, Yogyakarta: Pustaka Pelajar.

[4] Subkhan, Hoak Dalam Perspektif Islam, Makalah, disampaikan dalam Kajian Islam Bersama MUI Kudus, tanggal 5 Juli 2019.

[5] Satjipto Rahardjo, 2007, Membedah Hukum Progresif , Jakarta: Kompas.

[6] Soerjono Soekanto, 2004, Faktor-Faktor Yang Mempengaruhi Penegakan Hukum, Jakarta : PT. Raja Grafindo Persada.

\section{Regulation}

[1] Act No. 2 of 2002 concerning the Indonesian National Police.

[2] Act No. 11 of 2008 concerning Information and Electronic Transactions

[3] Regulation of the Head of the State Police of the Republic of Indonesia Number 6 of 2019 concerning Criminal Investigations.

[4] Circular Letter of the Chief of Police Number SE/2/II/2021 on Ethical Cultural Awareness to Create a Clean, Healthy, and Productive Indonesian Digital Space

\section{Journal}

[1] Eddy Santoso, Sri Endah Wahyuningsih, Umar Ma'ruf, "Peran Kepolisian Dalam Sistem Peradilan Pidana Terpadu Terhadap Penanggulangan Tindak Pidana Perjudian", Jurnal Daulat Hukum Vol. 1. No. 1 Maret 2018, url : http://jurnal.unissula.ac.id/index.php/RH/article/view/2632

[2] Humaizi, Siti Hazzah Nur Ritongga, "Upaya menanggulangi hoax melalui literasi media pada anggota Karang Taruna Desa Tandem Hilir I Kecamatan Hamparan Perak", Indonesian Journal of Community Services, Volume 1, No. 2, November 2019, url : http://jurnal.unissula.ac.id/index.php/ijocs/article/view/5004/3454

[3] Subhan HI. Ali Dodego, Pandangan Islam Tentang Hoaks Dan Ujaran Kebencian Dalam Konteks Kekinian (Telaah Tafsir Al-Qur'an Surah Al-Hujurat Ayat:6), url

https://pionir.uinmalang.ac.id/assets/uploads/berkas/artikel\%2018.pdf.

[4] Yanto Irianto, "Enforcement of Criminal Law In False News (Hoax) Management According To Law No. 11 In 2008 That Has Been Amended To Be Law No.19 of 2016 Concerning Electronic Information And Transactions In Islamic Law And Positive Laws", The 5th International Conference and Call for Paper Faculty of Law 2019 Sultan Agung Islamic University, url: http://jurnal.unissula.ac.id/index.php/apic/article/view/7854

[5] Zaldy Kurniawan, "Police Role In The Handing of Hate Speech", Jurnal Daulat Hukum, Volume 1 Issue 2, June 2018, url : http://jurnal.unissula.ac.id/index.php/RH/article/view/3260/2396

\section{Internet and Others}

[1] Kementrian Kominfo Catat 2000 Lebih Hoaks, 30 Persen Ujaran Kebencian, https://www.antaranews.com, accessed on 20 April 2021. 
[2] Lembaga Pendidikan dan Pelatihan Polri, Strategi Pencegahan Dan Penanganan Hoax, Sekolah Staf Dan Pimpinan Menengah, https://lemdik.polri.go.id, accessed on 30 June 2021.

\section{Interview}

[1] Results of an interview with Police Commissioner Victor Ziliwu, as staff of the Ditreskrimsus Polda Central Java, Semarang, on June 20, 2021 